\title{
ウシプロラクチンに関する免疫化学的研究
}

\author{
上家 哲・細田羍雄・ ${ }^{*}$ 五島 孝
}

(農林省畜座試験場・*静岡大学農学)

(1966. 6. 1 付部受)

乳牛の泌乳機能々下垂体ホルモンの相互の関連を解明 するためには血液中のホルモン量を正確に知ることが望 ましいが, 往来の生物学的測定方法はで血液中の微量の 下垂体ホルモンを定量することは極めて 困難であつた。 しかしながら最近急速に発展した蛋白質ホルモンの各種 の免疫化学的測定方法，特に radio immunoassay を态 用す机ば動物の血液中の下垂体ホルモンも人の場合と同 様測定できる可能性が充分考元られるい。

ウシ血液中のプロテクチン $(\mathrm{P})$ および成長ホルモン (GH)の免疫化学的測定法を検討するためにまずウシお よびヒッジのP と GHU対する抗血清をつくりその免 疫化学的性質を調べた チン (BP) の免疫化学的性質について報告する.Pkつ いての免疫化学的研究は比較的少〈 ${ }^{8 \sim 5)}$, 特に BP の詳 細な兔疫化学的性質については著者等の知名限りではそ の報告をみない。

\section{実験方 法}

ホルモン：実験に使用した次のホルモンは副腎皮質刺 激ホルモン (ACTH, Armour) を除いていずれも米国 国立衛生研究所 (NIH) から供与されたものである.

ウシプロラクチン (BP, $13 \mathrm{I} . \mathrm{U} / \mathrm{mg}, \mathrm{NIH}-\mathrm{P}-\mathrm{B} 1)$ ) 七 シジプロラクチン (SP, 24.8 I.U/mg, NIH-P-S 6), ウシ成長ホルモン (BGH, 0.8 USP/mg, NIH-GH-B 8), ヒッジ成長ホルモン (SGH, $1.6 \mathrm{USPU} / \mathrm{mg}, \mathrm{NIH}-\mathrm{GH}-$ S 6), ヒッジ卵胞刺游 ホルモン (SFSH, $0.87 \times$ NIHFSH-SI/mg, NIH-FSH-S 2), ウシ黄体刺激 ホルモン (BLH, $1.0 \times \mathrm{NIH}-\mathrm{LH}-\mathrm{SI} / \mathrm{mg}, \mathrm{NIH}-\mathrm{LH}-\mathrm{B} 2)$, ウシ甲 状腺刺戟ホルモン (BTSH, 3.52 USPU/mg, NIH-TSH $-B 2)$.

抗 BP 血清: BPをFREUND $の$ complete adjuvant 共に混合し，1 $\mathrm{mg}$ 成熟家无の右の前後の足踫皮内に 注射し，2 週間後同量の BP 左の前後の足蹠皮内に注 射した. この時期加ら 2 週間後および 4 週間後に $4 \mathrm{mg}$ ずつ背部皮下に注射した。最後の皮下注射加ら2 遇間後
に採血し抗血清を分離した。抗血清性 $56^{\circ} \mathrm{C} ， 30$ 分加熱 乙て非偣化し， $-20^{\circ} \mathrm{C}$ に保存した。

重層法: 下重体ホルモン，血清フルブミン等の抗原は 生理的食塩水で倍数稀䣋し，抗血清法 $2 \%$ フラビヤゴムー 食塩水で稀䣋した.

OUCHTERLONY 法：OUCHTERLONY6) の方法に基づき Special Noble Agar (Difco) せ $1.5 \%$ の滞度に生理的 食塩水で加熱溶解し防腐郕として窒化ソーダ $(0.1 \%)$ を 加えたものをシャーレに分注して固らせた. 寒天板の中 央の孔には抗血清を $0.15 \mathrm{~m} l$ ，周围の孔に惊原溶液を $0.1 \mathrm{~m} l$ 加光て沈降線出現の有無, 非状等を室温で観察 した.

免疫電気泳動法:GrABAR の方法により, Special Noble $\operatorname{Agar}(\operatorname{Difco})$ を $1.5 \%$ となるように $\mathrm{pH} 8.2$ ベロナール ソーダー塩酸緩衝液に溶解したものをガラス板上に固ら せ $2 \mathrm{~cm}$ 間隔に抗血清を入れる㴖をつくり,溝と满の中間 の直径 $0.3 \mathrm{~cm}$ の孔に抗原定标いた。電気泳動は $150 \mathrm{~V}$, $30 \mathrm{~mA}$ で 3 時間室温又は $4^{\circ} \mathrm{C} て ゙$ 行ない,泳動終了後抗血 清定满に加えて室温で免疫反応を観察した。

抗 BP 血清の抗ホルモン作用についての実験：抗 BP 血清が BP の生物学的作用を阻止するかどうがハトの

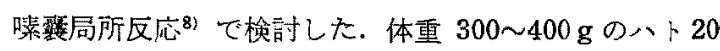
羽を 2 群に合け， A 群には BP の生理的食塩水溶液宾 $20 \mu \mathrm{g} / \mathrm{m} l$ 飞なるように，抗血清に加えてから， $37^{\circ} \mathrm{C} て ゙$ 1 特間加温し, $4^{\circ} \mathrm{C}$ で 15 時間放置したものを, $0.1 \mathrm{~m} l$ (P $2 \mu \mathrm{g})$ ずつ1日 1 回 4 日間右側嗦䇥皮内に注射した. B群の八トkは正常家蒐血清に BP $20 \mu \mathrm{g} / \mathrm{m} l$ になる ように混合したものをA 群の試料と同様に処理して, $0.1 \mathrm{~m} l$ ずつ注射した. 対象として BP $20 \mu \mathrm{g} / \mathrm{m} l$ の生理 的食塩水溶液を $0.1 \mathrm{~m} l$ ずつ 4 日間 $\mathrm{A}$ 怙よびB群の八ト

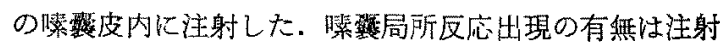
開始後 5 日目に観察した.

下垂体粗抽出液の調整：(ホルスタイン仔牛, 雄),ヤ ギ (ザーネン成, 此)，ヒッジ(成维)，ウマ(成)，ブタ

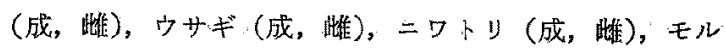


ウシプロラクチンに関する免疫化学的研究

モット，成雌）、シット（成，雌）から採取した下垂体 怡生理的食塩水を加光てガラスホモジェナイザーで磨 研し，その粗抽出液について抗 BP 血清に対する免疫反 疬の有無を, OUCHTERLONY 法拉よび免疫電気泳動法で 観察した.

\section{実 験 結 果}

重層法: BP を FREUND の complete adjuvant と共に ウサギの足踫および皮下に注射して得た抗 BP 血清は $100 \mu \mathrm{g} / \mathrm{m} l$ の BP に対して 64 倍稀釈まで沈降線が認め られた. 各種精製下垂体ホルモンに対する免疫反応を表 1 に示した. BP およびSP に対しては $2 \mu \mathrm{g} / \mathrm{m} l$ まで沈 降線が出現したが，BLH，SFSH，BLH，に対する反応 将陰性かまたは極めて弱かつた，BGH および SGH に
対する沈降線の出現は精製 GH に混入しているPによ るものと考元られる9).

OUCHTERLONY 法: OUCHTERLONY 法では抗 BP 血清は 実験に使用した下垂体ホルモンの中 BP および SP に対 して $5 \mu \mathrm{g}$ 以下でむ明瞭な沈降線を形成するが，BTSH，

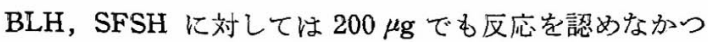
た. BGH, SGH に対しては高濃度 $(100 \mu \mathrm{g})$ の場合 BP および SP と全く同様な沈降線が認められたが $5 \mu \mathrm{g}$ で は認められなかつた（Fig. 1 および 2).

ウシ,ヒッジ, ウマ,ヤギ, ブタの血清に対する明膫な 反応は観察できなかつた（表 2). ウシ，ヤギ，ヒッジ の下垂体粗抽出物は抗 BP 血清に対して精製 $\mathrm{P}$ と同一の 沈降線を形成するが, ウマ,ブタ, ウサギ,ラット,ニワ トリの場合は沈降線を認めなかつた（表 3 ), (Fig. 3).

Table 1. Precipitin ring tests with bovine prolactin antiserum

\begin{tabular}{|c|c|c|c|c|c|c|c|c|c|c|c|c|c|}
\hline Antiserum & Antigen & \multicolumn{11}{|c|}{ Antigen dilution $(\mu \mathrm{g})$} & 1 \\
\hline \multirow{9}{*}{ Not absorbed } & Bovine prolactin & + & + & + & + & + & + & + & + & + & + & + & - \\
\hline & Ovine prolactin & + & + & + & + & + & + & + & + & + & + & + & - \\
\hline & Bovine GH & $(+)^{*}$ & $(+) *$ & ${ }^{*}(+)^{*}$ & $(+) *$ & $*(+)$ & $*(+)$ & - & - & - & - & - & - \\
\hline & Ovine GH & $(+) *$ & $(+) *$ & $*(+) *$ & $(+)^{*}$ & $*(+)$ & $*(+)$ & - & - & - & - & - & - \\
\hline & Bovine TSH & \pm & - & - & - & - & - & - & - & - & - & - & - \\
\hline & Bovine LH & - & - & - & - & - & - & - & - & - & - & - & - \\
\hline & Ovine FSH & - & - & - & - & - & - & - & - & - & - & - & - \\
\hline & $\mathrm{ACTH}$ & - & - & - & - & - & - & - & - & - & - & - & - \\
\hline & Bovine serum albumine & - & - & - & - & - & - & - & - & - & - & - & - \\
\hline
\end{tabular}

* The bovine and ovine GH Preparations are contaminated with prolactin.

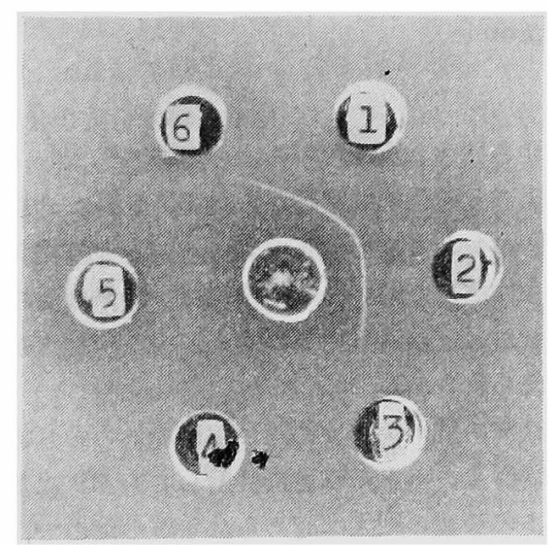

Fig. 1. Gel diffusion by the Ouchterlony method. Center well: antiserum to BP; well 1: BP, $10 \mu \mathrm{g}$; well $2: \mathrm{SP}, 10 \mu \mathrm{g}$; well 3 : BGH, $10 \mu \mathrm{g}$; well $4:$ BTSH, $100 \mu \mathrm{g}$; well 5: $\mathrm{BLH}, 100 \mu \mathrm{g}$; well 6: SFSH, $100 \mu \mathrm{g}$.

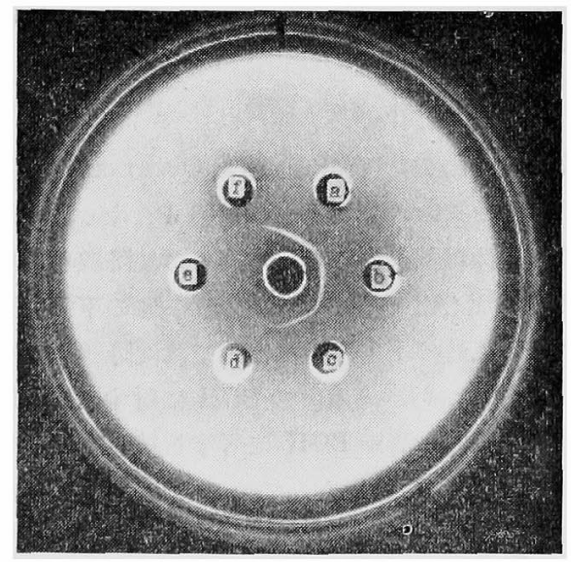

Fig. 2. Gel diffusion by the Ouchterlony method. Center well: antiserum to $\mathrm{BP}$; well a: BP, $20 \mu \mathrm{g}$; well b: SP, $20 \mu \mathrm{g}$; well c: $\mathrm{BGH}, 100 \mu \mathrm{g}$; well d: SGH, $100 \mu \mathrm{g}$; well e: bovine serum albumine, $200 \mu \mathrm{g}$; well $\mathrm{f}$ : normal bovine serum. 


\section{上家・細田・五島}

Table 2. Results of gel diffusion studies of anterior pituitary hormones and sera. to BP antiserum (OuCHTERLONY and immunoelectrophoresis)

\begin{tabular}{|c|c|c|c|c|c|c|c|c|c|c|c|c|}
\hline Materials & $\mathrm{BP}$ & $\mathrm{SP}$ & $\mathrm{BGH}$ & BTSH & $\mathrm{BLH}$ & SFSH & $\mathrm{ACTH}$ & $\begin{array}{c}\text { Bovine serum } \\
\text { albumine }\end{array}$ & $\begin{array}{l}\text { Bovine } \\
\text { serum }\end{array}$ & $\begin{array}{l}\text { Sheep } \\
\text { serum }\end{array}$ & $\begin{array}{l}\text { Goat } \\
\text { serum }\end{array}$ & $\begin{array}{l}\text { Horse } \\
\text { serum }\end{array}$ \\
\hline Reaction to antiserum & + & + & - & - & - & - & - & - & - & - & - & - \\
\hline
\end{tabular}

Table 3. Immunological interactions of pituitary extracts from several species with antiserum to BP (OuchterlonY and immunoelectrophoresis)

\begin{tabular}{l|cccccccccc}
\hline \hline Saline Pituitary extracts & Cattle & Goat & Sheep & Pig & Horse & Rabbit & Guirea pig & Rat & Chicken \\
\hline Reaction to antiserum & + & + & + & - & - & - & - & - & - & $r$ \\
\hline
\end{tabular}

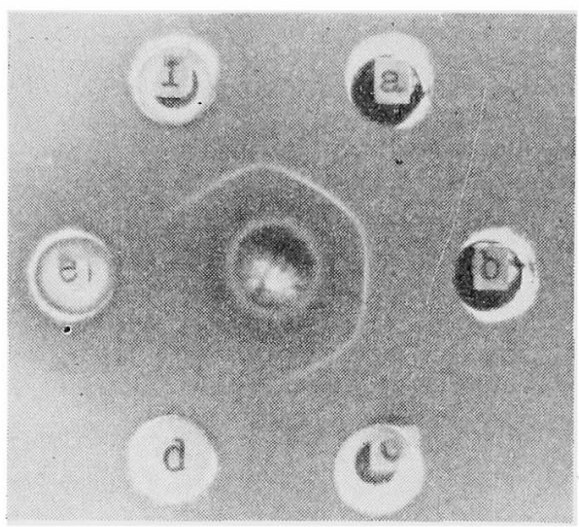

Fig. 3. Gel diffusion by the OuchterLony method. Center well: antiserum to BP; well a: BP, $15 \mu \mathrm{g}$; well b: SP, $15 \mu \mathrm{g}$; well c: saline homogenate of goat's pituitary gland; well d: saline homogenate of porcine pituitary gland; well e; saline homogenate of equine pituitary gland; well $f$ : saline homogenate of bovine pituitary gland.

免疫電気泳動法：抗 BP 血清は OUCHTERLONY 法の場 合と同様, ウシおよびヒッジの精製 $\mathrm{P}$ ，ウシ，ヒッジ, ヤギの下垂体粗抽出物に対して同一の沈降線を形成した が, ウシおよびヒッジの GH を除く他の下垂体ホルモ ン, 反忽類以外の下垂体粗抽出物では沈降線を観察でき なかつた (Fig. 4). 高浱度の BGH に対する抗 BP 血清 の反応は抗 BP 血清が BGH に対する抗体を含んでいる のではなくて GH に混在している P(1.0 I.U./mg)そ のものに由来する反応と考光られる．即ち免疫電気泳動 像において観察される BGH の抗 BP 血清に対する沈降 線は BP の沈降線と完全に一致するが, BPで吸収した抗 $\mathrm{BGH}$ 血清に対する $\mathrm{BGH}$ そのものの沈降線とは明らか に異つているからである. また逆にこの精製 BGH でつ くつた抗 BGH 血清は, BGH に対する抗体以外にも BP

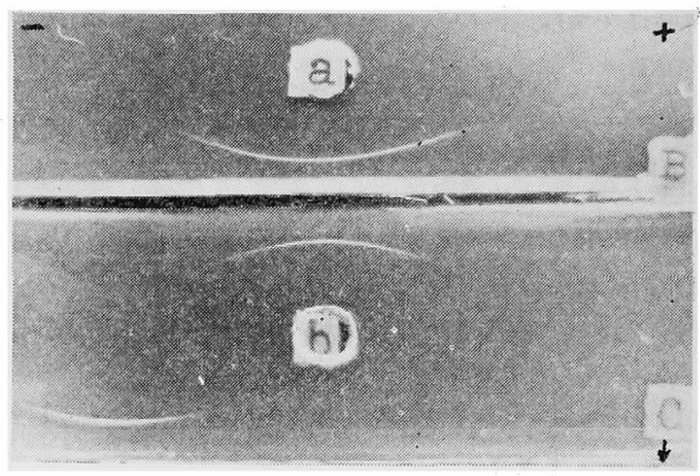

Fig. 4. Immunoelctrophoretic analysis of BP and a saline homogenate of pituitary gland. Well a: BP, $10 \mu \mathrm{g}$; well b: saline homogenate of bovine pituitary gland; trough $\mathrm{B}$ : antiserum to $\mathrm{BP}$; trough $\mathrm{C}$ : antiserum to $\mathrm{BGH}$ (absorbed free of antibodies to $\mathrm{BP}$ and bovine serum protein).

に対する抗体も含えでいるからである91.

以上の免疫化学的実験から抗 $\mathrm{BP}$ 血清は $\mathrm{P}$ 以外の下垂 体ホルモンおよび血清蛋白質に対する免疫交叉反店が陰 性または極めて弱いので免疫に用いた $\mathrm{P}$ は他の下垂体木 ルモンおよび血清蛋白質の混入が少なく純度が高いもの と考元れる.

抗血清の抗ホルモン作用：BP をあらかじめ抗 BP 血

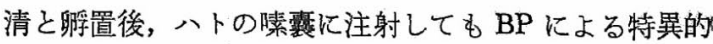
なハトの嘹霬の肥大は認められなかつたので, 抗 BP 血 清は BP の生物学的作用を完全に阻止したものと考光ら れる (表 4). 同㥞な方法で 正常家鬼血清と BP を瞬置 したものをハトに注射した群では $\mathrm{P}$ の生物学的作用には 变化が認められなかつた。 
Table 4. The influence of BP antiserum on the biological activity of BP determined by the pigeon crop-sac test

\begin{tabular}{l|ccc}
\hline Group of experiment & $\begin{array}{c}\text { Total } \\
\text { prolactin } \\
\text { injected } \\
\text { per pigeon }\end{array}$ & $\begin{array}{c}\text { Number } \\
\text { of } \\
\text { pigeons }\end{array}$ & $\begin{array}{c}\text { Local } \\
\text { reaction }\end{array}$ \\
\hline $\begin{array}{l}\text { BP solution in saline } \\
\text { BP solution in normal }\end{array}$ & $8 \mu \mathrm{g}$ & 10 & + \\
$\begin{array}{l}\text { rabbit serum } \\
\text { BP solution in BP } \\
\text { antiserum }\end{array}$ & $8 \mu \mathrm{g}$ & 10 & + \\
\hline
\end{tabular}

\section{考察}

1961 年 LEVY および SAMPLINER ${ }^{3)}$ は SP (Armour 15 I.U/mg）火対与る抗血清家つくることに最初に成功し たが続いて HAYASHIDA ${ }^{\text {() }}$ は，LIの方法により抽出精留し たSPに対する抗血清が $\mathrm{P}$ に対して特買的に免疫反応を 示し，ラットおよび人の下垂体抽出物に対しては免疫反 応を示さず種特異性があること報告している，著者等 の実験結果でも抗 BP 血清の免疫化学的反忘は P k詨し てホルモン特貲的であり，また種特異性が強いことを示 している. 穼た抗 BP 血清の免疫化学的性質は抗 SP 血 清の性質と著しく類似して和り $\mathrm{NIH}$ の $\mathrm{BP}, \mathrm{SP}$ 共に他 の下垂体ホルモン，血清蛋白質の混入が少なく純度が高 いるのと考元られる 作用が抗 SP 血清によつて阻止されることをハトの㗪装 重量法によつて証明したが，抗 BP 血清も同樣にBP の

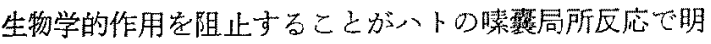
らかになった。

免疫化学的実験の結果注, NIH のウシのP は比較的 純度が高く，また反聯類のPの中少なくともウシ，ヒッ ジヤ抽の Pの蛋白質構造注同一でないとして子相互に 類似しているが，ブタ、ニワトリ，シット等のPと爯 造が異ることを示している。適当な方法を用いれば微量 のウシのPをウシまたはヒッジ抗P血清によつて免疫化 学的に定量することは可能であるが，プタ、ニワトリ。 ラット等の P $\mathrm{BP}$ あるいは SP に齐する抗血清を用い て定量することは困難と考劣られる。
要約

ウシプロラクチン (BP) vant と共にウサギの足踫皮内㧍よび背部皮下に注射し て抗 BP血清苍つくり免瘦化学的性質党検討した。

1） BP 注ヒッジプロラタチン (SP) と同㥞にウサギ に対してかなり強い抗原性示した。

2) 抗 BP 血清はプロラクチン (P) に対して特異的 飞免疫反店を示し $\mathrm{P}$ 以外の下垂体ホルモンに対与る兔疫 交又区応法陰性加極好弱以。

3）ウシ，ヒッジ，ヤ代等の反忽類の下垂体性 $\mathrm{P}$ 注抗 BP 血清衹対して同一の免疫交文反応を示すがウマ，ブ タ, ウサギ，ラット，二ワトリ等の $\mathrm{P} て ゙ は$ 明瞭な沈降線 を観察することは出来な名った。

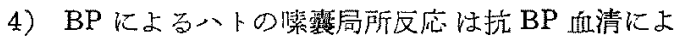
つて完全に阻止された。

\section{Acknowledgment}

The authors wish to thank the generous supplies of purified pituitary hormones from the Eodocrinology Study Section, National Institute of Health, U.S.A.

\section{文献}

1）上家 哲（1966）日内分泌会誌，41：別号，55.

2）上家 哲・阿部恒夫・細田達雄・五島 孝(1965) 日畜会報, 36: 別号, 24 .

3) Levy, R.P. and J. Samplinlr (1961) Proc. Soc. Exp. Biol. Med., 106: 214.

4) Hay ashida, T. (1962) Chiba Foundation Colloq. on Endocrinol., 14: 338.

5）正田陽一・阿部恒夫・細田達雄（1966）日盲会報, 37: 別号, 9.

6) Ouchterlony, O. (1953) Acta Pathol. Microbiol. Scand., 32: 231.

7) Grabar, P. (1959) Methods of Biochemical Analysis, 7: 3. Interscience Publ. Inc. New York.

8) Regce, R. P. and C. W. Turner (1937) Res. Bull. Mo. Agr. Expt. Sta. 266.

9）上家 哲 - 阿部恒夫 - 布施 洋 - 細田達雄 五島 孝（1966） 日畜会報，37：401 406. 


\title{
Résumé
}

\section{Immunochemical Investigations of Bovine Prolactin}

\author{
Tetsu JoHKE*, Tatsuo HosodA*, and Takashi Goto** \\ (* National Institute of Animal Industry, Chiba-city) \\ (** School of Agriculture, Shizuoka University, Iwata-city)
}

The antisera to bovine prolactin preparation (NIH-P-BI) were obtained by intradermal injections of prolaction with Freund's complete adjuvant to rabbit's foot pads and subcutaneously. The characteristics of antisera were determined by precipitin ring test, OuchterLoNY diffusion test and anti-hormone test.

1) Bovine and ovine prolactin preparations showed complete immunological cross reactions against bovine prolactin antisera. There were no detectable precipitin lines with serum proteins and other pituitary hormones except bovine and ovine growth hormone preparations at high concentration in gel diffusion studies. The immunological cross reactions with bovine and ovine growth hormone preparations were originated from the contaminating prolactin in the growth hormone preparations and not from growth hormone itself.

2) The antisera showed complete immunological cross reactions with bovine, ovine and goat's pituitary extracts as in the case of purified bovine and ovine prolactin. On the other hand, the pituitary extracts from horse, pig, rabbit, rat and chicken did not show any remarkable cross reactions against bovine prolactin antisera.

3) The pigeon's local crop-sac reaction with bovine prolactin was completely inhibited by antisera to bovine prolactin. 